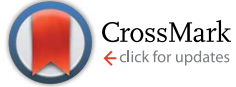

Cite this: RSC Adv., 2017, 7, 11206

Received 19th December 2016 Accepted 28th January 2017

DOI: 10.1039/c6ra28419a

rsc.li/rsc-advances

\section{A novel water soluble chemosensor based on carboxyl functionalized NDI derivatives for selective detection and facile removal of mercury(II) $\dagger$}

\author{
Qi Lin, ${ }^{\star a}$ Peng-Peng Mao, ${ }^{a}$ Lu Liu, ${ }^{a}$ Juan Liu, ${ }^{* b}$ You-Ming Zhang, ${ }^{a}$ Hong Yao ${ }^{a}$ \\ and Tai-Bao Wei*a
}

\begin{abstract}
Mercury(II) $\left(\mathrm{Hg}^{2+}\right)$ has acute toxicity. It is still a challenge to design and synthesize chemosensors for selective detection and removal of $\mathrm{Hg}^{2+}$ in water solutions. By rationally combining the carboxyl group and naphthalene diimide moieties, we obtained a novel water-soluble $\mathrm{Hg}^{2+}$ chemosensor (M2). Interestingly, the sensor M2 showed a dramatic fluorescent "turn-on" response for $\mathrm{Hg}^{2+}$ in water. Moreover, the sensor $\mathrm{M} 2$ displayed a high specificity for $\mathrm{Hg}^{2+}$, other cations (including $\mathrm{Fe}^{3+}, \mathrm{Ag}^{+}, \mathrm{Ca}^{2+}, \mathrm{Cu}^{2+}, \mathrm{Co}^{2+}, \mathrm{Ni}^{2+}, \mathrm{Cd}^{2+}, \mathrm{Pb}^{2+}, \mathrm{Zn}^{2+}$, $\mathrm{Cr}^{3+}$, and $\mathrm{Mg}^{2+}$ ) had no influence on the $\mathrm{Hg}^{2+}$ detection process. Moreover, the sensor $\mathrm{M} 2$ showed high sensitivity for $\mathrm{Hg}^{2+}$, with detection limits of $1.18 \times 10^{-6} \mathrm{M}$. Even more meaningfully, the sensor $\mathrm{M} 2$ can remove $\mathrm{Hg}^{2+}$ from water solutions effectively via the formation of a $\mathrm{M} 2-\mathrm{Hg}^{2+}$ coordination polymer, which can increase the possibility of M2 being used for practical applications.
\end{abstract}

\section{Introduction}

As we all know, ions play a significant role in life and technological processes..$^{1-4}$ Moreover, heavy metal ions pose a big threat to human health and the environment due to their high toxicity and bioaccumulation. ${ }^{5,6}$ Among the heavy metals, mercury is one of the most toxic. ${ }^{7-11}$ However, large quantities of mercury salts are widely used in industrial chemicals, electricals, apparatus, dental amalgams, and batteries. ${ }^{12-15}$ Hence, the rational design and synthesis of efficient sensors to selectively detect and remove $\mathrm{Hg}^{2+}$ ions has attracted much attention. ${ }^{16-18}$ Moreover, due to most of the biological or environmental procedures being carried out in water systems, it is very important to develop a $\mathrm{Hg}^{2+}$ chemosensor, which can detect and remove $\mathrm{Hg}^{2+}$ in water.

Thus far, some methods based on organic fluorophores ${ }^{19}$ or chromophores, ${ }^{20}$ semiconductor nanocrystalline materials, ${ }^{21}$ cyclic voltammetry, ${ }^{22}$ polymeric materials, ${ }^{23}$ and proteins ${ }^{24}$ have been established for the detection of $\mathrm{Hg}^{2+}$. However, most of these materials are difficult to be applied in the detection of mercury ions in water solutions due to their poor water

${ }^{a}$ Key Laboratory of Eco-Environment-Related Polymer Materials, Ministry of Education of China, Key Laboratory of Polymer Materials of Gansu Province, College of Chemistry and Chemical Engineering, Northwest Normal University, Lanzhou, Gansu, 730070, P. R. China.E-mail: linqi2004@126.com; weitaibao@126.com

${ }^{b}$ College of Chemical Engineering, Northwest University for Nationalities, Lanzhou, 730000, P. R. China. E-mail: liujuan656@126.com

$\dagger$ Electronic supplementary information (ESI) available: Experimental details, synthesis of M2, NMR spectra, and other materials. See DOI: 10.1039/c6ra28419a solubility. Moreover, these chemosensors cannot remove $\mathrm{Hg}^{2+}$ in water simultaneously. Therefore, the search for effective sensing systems in a water environment is still a great challenge. At the same time, various absorbents, such as activated carbon, ${ }^{25}$ resins, ${ }^{26}$ silica, ${ }^{27}$ zeolites $^{28}$ and metal sulfides ${ }^{29}$ have been applied to remove $\mathrm{Hg}^{2+}$ from wastewater; however, these absorbents cannot detect $\mathrm{Hg}^{2+}$ in water. The reports on simultaneous detection and removal of $\mathrm{Hg}^{2+}$ in water are still very scarce. ${ }^{30-33}$ Therefore, the development of water soluble $\mathrm{Hg}^{2+}$ chemosensors, which can synchronously detect and remove $\mathrm{Hg}^{2+}$ in water is an important task.

In view of this and based on our research in ion recognition, ${ }^{34,35}$ we report a water-soluble $\mathrm{Hg}^{2+}$ sensor $\mathbf{M 2}$ based on naphthalene diimide derivatives. In order to achieve fluorescent sensing and efficient removal of $\mathrm{Hg}^{2+}$ in water, we rationally introduced the carboxyl group into the sensor molecule as a hydrophilic group and $\mathrm{Hg}^{2+}$ binding site. Moreover, we introduced a naphthalene diimide moiety as the fluorescent signal group and $\pi-\pi$ stacking site. As a result, the sensor M2 showed good solubility in water and could fluorescently "turn on" when it detected $\mathrm{Hg}^{2+}$ with high selectivity and sensitively in water solution. More interestingly, the sensor M2 could efficiently remove $\mathrm{Hg}^{2+}$ in water simultaneously.

The sensor M2 was synthesized by a simple dehydration condensation procedure (Scheme 1) and was characterized by ${ }^{1} \mathrm{H}$ NMR spectroscopy and ESI-MS (Fig. S1 and S2 $\dagger$ ). The recognition properties of the chemosensor $\mathbf{M} 2$ towards various metal cations, such as $\mathrm{Fe}^{3+}, \mathrm{Hg}^{2+}, \mathrm{Ca}^{2+}, \mathrm{Cu}^{2+}, \mathrm{Co}^{2+}, \mathrm{Ni}^{2+}, \mathrm{Cd}^{2+}$, $\mathrm{Pb}^{2+}, \mathrm{Zn}^{2+}, \mathrm{Ag}^{+}, \mathrm{Cr}^{3+}$, and $\mathrm{Mg}^{2+}$, were primarily investigated by 

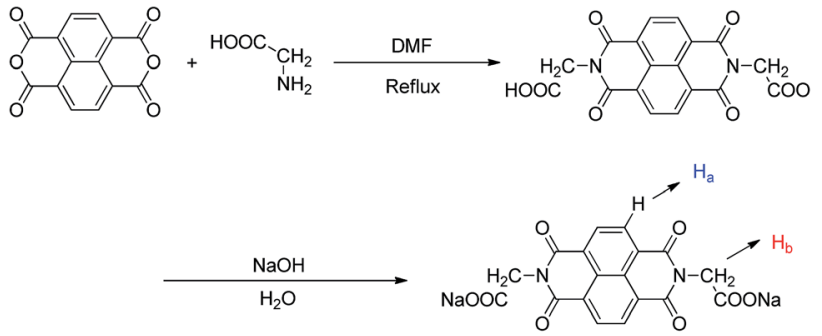

M2

Scheme 1 Synthesis of compound M2.

fluorescence emission spectra in water solution (buffered with HEPES, $\mathrm{pH}=7.2$ ). The compound $\mathbf{M} 2$ alone displayed no fluorescence when it was excited at $365 \mathrm{~nm}$ (Fig. 1). However, when 10 equiv. of $\mathrm{Hg}^{2+}$ was added to the water solution of $\mathbf{M 2}$ $\left(2.0 \times 10^{-4} \mathrm{M}\right)$, the solution emitted bright blue fluorescence emission. Simultaneously, in the fluorescence spectrum, an emission peak at $425 \mathrm{~nm}$ could be observed (Fig. S3†). To validate the selectivity of sensor $\mathbf{M} 2$ for $\mathrm{Hg}^{2+}$, the same tests were carried out for other cations (including $\mathrm{Fe}^{3+}, \mathrm{Ca}^{2+}, \mathrm{Cu}^{2+}, \mathrm{Co}^{2+}$, $\mathrm{Ni}^{2+}, \mathrm{Cd}^{2+}, \mathrm{Pb}^{2+}, \mathrm{Zn}^{2+}, \mathrm{Cr}^{3+}, \mathrm{Ag}^{+}$, and $\left.\mathrm{Mg}^{2+}\right)$; however, these cations could not induce any significant fluorescent changes in the fluorescence spectrum (Fig. 1). These results indicate that the sensor M2 can selectively fluorescently "turn-on" when sensing $\mathrm{Hg}^{2+}$ in water solution.

To further investigate the interaction between sensor $\mathbf{M} 2$ and $\mathrm{Hg}^{2+}$, the fluorescence emission spectral variation of sensor M2 $\left(2.0 \times 10^{-4} \mathrm{M}\right)$ in water (buffered with HEPES, $\left.\mathrm{pH}=7.2\right)$ was recorded during titrations with different concentrations of $\mathrm{Hg}^{2+}$. As shown in Fig. 2, with the addition of increasing

(a)

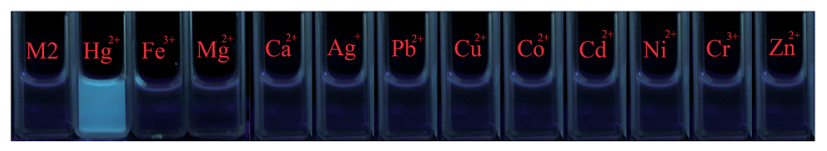

(b)

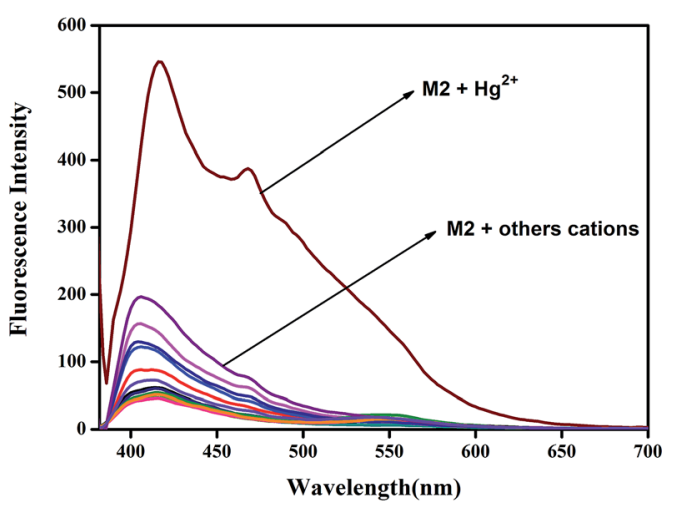

Fig. 1 (a) Photograph of M2 upon adding 10 equiv. of various cations in, which was taken under an UV-lamp $(365 \mathrm{~nm})$ at room temperature. (b) Fluorescence spectra responses in water solution (buffered with HEPES, $\mathrm{pH}=7.2)$ of $\mathrm{M} 2\left(2.0 \times 10^{-4} \mathrm{M}\right)$ upon addition of different cations (10 equiv.). concentrations of $\mathrm{Hg}^{2+}$ from 0 to 3.26 equiv., the emission peak at $425 \mathrm{~nm}$ gradually enhanced. Furthermore, in order to determine the detection limits of $\mathbf{M} 2$ for $\mathrm{Hg}^{2+}$, the fluorescence spectra of blank tests were measured 20 times and the standard deviation of the blank measurements was determined (Fig. S4 $\dagger$ ). The fluorescence quantum yield $(\Phi)$ of sensor M2 in water is 0.03 with quinine hemisulfate salt as a reference while the $\Phi$ increased to 0.32 when sensor $\mathbf{M} 2$ reacts with $\mathrm{Hg}^{2+}$ (see ESI $\dagger$ ). The linear fitting was performed according to the titration curves, and the mean intensity was calculated to determine the slope. The limit of detection (LOD) was determined from the equation LOD $=K \times \sigma / S,{ }^{36}$ where $K=3, \sigma$ is the standard deviation of the emission intensity of $\mathbf{M} 2$ in the presence of $\mathrm{Hg}^{2+}$, and $S$ is the slope of the calibration curve of the fluorescence emission. The detection limit of the fluorescence spectrum was $1.18 \times 10^{-6} \mathrm{M}$. This data indicate that the sensor can detect $\mathrm{Hg}^{2+}$ at very low concentrations in the environment (Fig. S5 $\dagger$ ). Moreover, the binding constant $(K)$ derived from the fluorescence titration data was found to be $2.65 \times 10^{9} \mathrm{M}$ (see ESI†) using a Benesi-Hildebrand plot, ${ }^{37}$ which indicates a high detection sensitivity.

Then, the competition experiments were also measured by the addition of 10 equiv. of $\mathrm{Hg}^{2+}$ to the water solution of $\mathbf{M} 2$ in the presence of 10 equiv. of other metal ions, such as $\mathrm{Fe}^{3+}, \mathrm{Ca}^{2+}$, $\mathrm{Cu}^{2+}, \mathrm{Co}^{2+}, \mathrm{Ni}^{2+}, \mathrm{Cd}^{2+}, \mathrm{Pb}^{2+}, \mathrm{Zn}^{2+}, \mathrm{Cr}^{3+}, \mathrm{Ag}^{+}$and $\mathrm{Mg}^{2+}$. As shown in Fig. 3, the effect on emission intensity of $\mathbf{M 2}$ upon the addition of higher concentrations of various cations was almost negligible. These results revealed that M2 had a remarkable selectivity towards $\mathrm{Hg}^{2+}$ over competitive ions, and moreover, the detection of $\mathrm{Hg}^{2+}$ by $\mathbf{M} 2$ was hardly affected by these common coexisting cations in water (buffered with HEPES, $\mathrm{pH}$ $=7.2$ ). Moreover, in order to investigate the influence of coexisting anions on the $\mathrm{Hg}^{2+}$ sensing process, the competition experiments were also carried out by adding various anions into the $\mathbf{M} 2-\mathrm{Hg}^{2+}$ water solution (Fig. 4). As a result, coexisting anion ions, such as $\mathrm{F}^{-}, \mathrm{Cl}^{-}, \mathrm{Br}^{-}, \mathrm{I}^{-}, \mathrm{Ac}^{-}, \mathrm{H}_{2} \mathrm{PO}_{4}^{-}, \mathrm{HSO}_{4}^{-}, \mathrm{HClO}_{4}^{-}$, $\mathrm{SCN}^{-}$and $\mathrm{CN}^{-}$, could not interfere in the $\mathrm{Hg}^{2+}$ sensing process of $\mathbf{M} 2$.

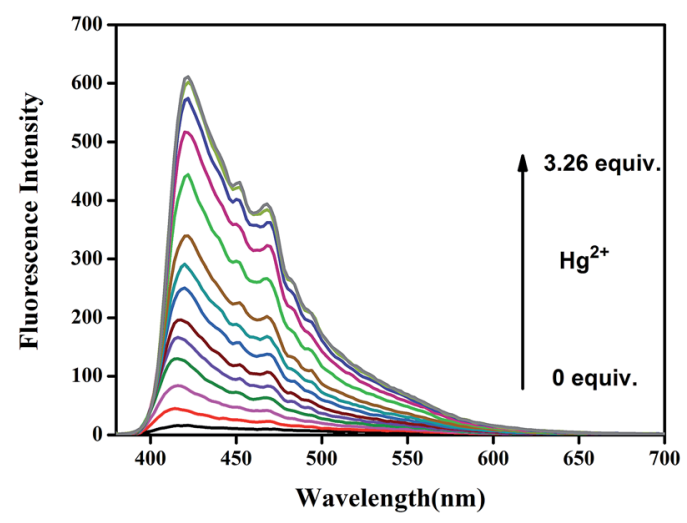

Fig. 2 Fluorescence titration spectra of $\mathrm{Hg}^{2+}$ in water solution (buffered with HEPES, $\mathrm{pH}=7.2$ ) upon addition of increasing concentration of $\mathrm{Hg}^{2+}$. 


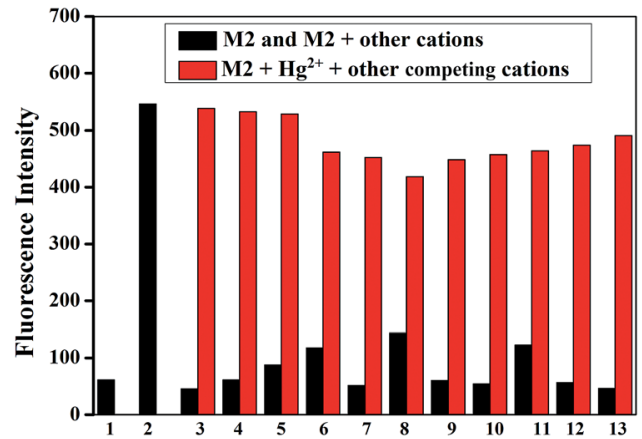

Fig. 3 Fluorescent emission $\left(\lambda_{\text {ex }}=365 \mathrm{~nm}\right)$ spectra of $\mathrm{M} 2\left(2 \times 10^{-4} \mathrm{M}\right)$ to $\mathrm{Hg}^{2+}(10$ equiv.) in the presence of various competing cations in water (buffered with HEPES, $\mathrm{pH}=7.2$ ). Form 1 to $12: \mathrm{M} 2, \mathrm{M} 2+\mathrm{Hg}^{2+}$, $\mathrm{M} 2+\mathrm{Hg}^{2+}+\mathrm{Fe}^{3+}, \mathrm{M} 2+\mathrm{Hg}^{2+}+\mathrm{Ca}^{2+}, \mathrm{M} 2+\mathrm{Hg}^{2+}+\mathrm{Cu}^{2+}, \mathrm{M} 2+\mathrm{Hg}^{2+}+$ $\mathrm{Co}^{2+}, \mathrm{M} 2+\mathrm{Hg}^{2+}+\mathrm{Ni}^{2+}, \mathrm{M}^{2+}+\mathrm{Hg}^{2+}+\mathrm{Cd}^{2+}, \mathrm{M} 2+\mathrm{Hg}^{2+}+\mathrm{Pb}^{2+}, \mathrm{M} 2+$ $\mathrm{Hg}^{2+}+\mathrm{Zn}^{2+}, \mathrm{M} 2+\mathrm{Hg}^{2+}+\mathrm{Ag}^{+}, \mathrm{M} 2+\mathrm{Hg}^{2+}+\mathrm{Cr}^{3+}, \mathrm{M} 2+\mathrm{Hg}^{2+}+\mathrm{Mg}^{2+}$.

As we all know, the pH has a strong influence on the coordination properties of ligands and metal ions. Therefore, the effects of $\mathrm{pH}$ on the $\mathrm{Hg}^{2+}$ sensing process were also investigated (Fig. 5). Over the tested $\mathrm{pH}$ range, sensor M2 alone had no fluorescence and was stable in the $\mathrm{pH}$ range 4.0-13.0. However, the $\mathbf{M} 2-\mathrm{Hg}^{2+}$ complex showed a significant fluorescence response between $\mathrm{pH} 4.0$ and 8.0. These results indicate that $\mathrm{Hg}^{2+}$ could be clearly detected by the fluorescence spectral measurement using $\mathbf{M} 2$ over a $\mathrm{pH}$ range from 4.0 to 8.0. In acidic conditions, carboxylate groups in $\mathbf{M 2}$ changed to carboxylic acids, whereas, in alkaline conditions, the $\mathrm{Hg}^{2+}$ could form $\mathrm{Hg}(\mathrm{OH})_{2}$. In either case, the coordination abilities of $\mathbf{M 2}$ and $\mathrm{Hg}^{2+}$ were restrained. Moreover, in strongly acidic $(\mathrm{pH}<1)$ or strongly alkaline conditions ( $\mathrm{pH}>13$ ), the sensor M2 showed unusual fluorescence, which indicated the $\mathbf{M 2}$ is unstable in these conditions.

The recognition mechanism of the sensor $\mathbf{M} 2$ with $\mathrm{Hg}^{2+}$ was primarily investigated by IR spectroscopy. In the IR spectrum of

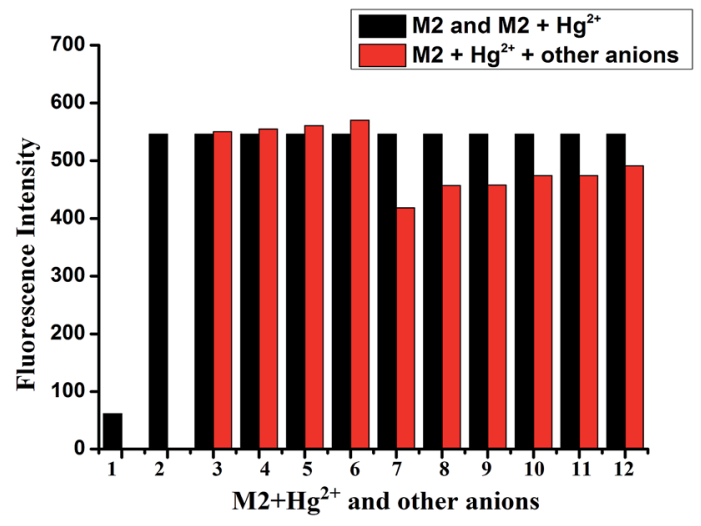

Fig. 4 Fluorescent emission $\left(\lambda_{\text {ex }}=365 \mathrm{~nm}\right)$ spectra of $\mathrm{M} 2\left(2 \times 10^{-4} \mathrm{M}\right)$ to $\mathrm{Hg}^{2+}$ (10 equiv.) in the presence of various anion ions (10 equiv.) in water (buffered with HEPES, $\mathrm{pH}=7.2$ ). Form 1 to 12 : $\mathrm{M} 2, \mathrm{M} 2+\mathrm{Hg}^{2+}$, $\mathrm{M} 2+\mathrm{Hg}^{2+}+\mathrm{F}^{-}, \mathrm{M} 2+\mathrm{Hg}^{2+}+\mathrm{Cl}^{-}, \mathrm{M} 2+\mathrm{Hg}^{2+}+\mathrm{Br}^{-}, \mathrm{M} 2+\mathrm{Hg}^{2+}+\mathrm{I}^{-}$, $\mathrm{M} 2+\mathrm{Hg}^{2+}+\mathrm{Ac}^{-}, \mathrm{M} 2+\mathrm{Hg}^{2+}+\mathrm{H}_{2} \mathrm{PO}_{4}^{-}, \mathrm{M}^{2}+\mathrm{Hg}^{2+}+\mathrm{HSO}_{4}^{-}, \mathrm{M} 2+$ $\mathrm{Hg}^{2+}+\mathrm{ClO}_{4}^{-}, \mathrm{M} 2+\mathrm{Hg}^{2+}+\mathrm{SCN}^{-}, \mathrm{M} 2+\mathrm{Hg}^{2+}+\mathrm{CN}^{-}$.

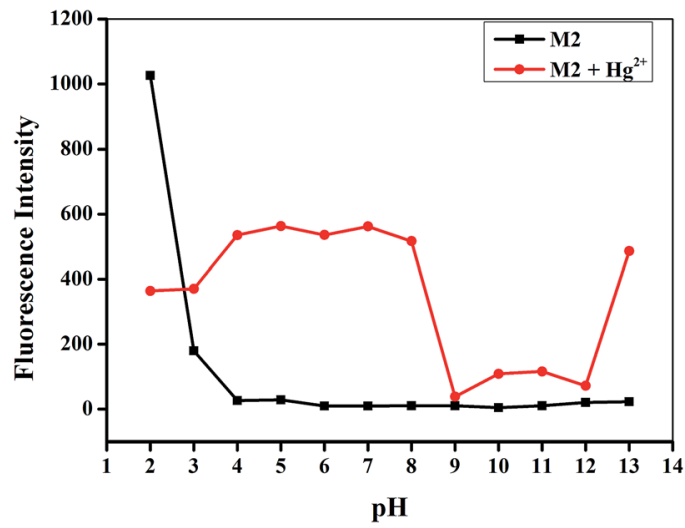

Fig. 5 Effect of $\mathrm{pH}$ on the fluorescence spectra of $\mathrm{M} 2(20 \mu \mathrm{M})$ in response to $\mathrm{Hg}^{2+}$ (10 equiv.) from $\mathrm{pH} 2.0$ to 13.0 in water solution.

M2 (Fig. 6), the carboxyl groups show the stretching vibrations absorption peak at $1715 \mathrm{~cm}^{-1}$. However, after the addition of $\mathrm{Hg}^{2+}$, this peak shifts to $1663 \mathrm{~cm}^{-1}$, which indicates that M2 bonds to $\mathrm{Hg}^{2+}$ via carboxyl groups. In addition, the mass spectroscopy results also supported this presumption. The ion peak at $\mathrm{m} / \mathrm{z} 582.60$ demonstrated the presence of $\left[\mathbf{M} 2+\mathrm{Hg}^{2+}\right]$ (Fig. S7 †).

The recognition mechanism of the sensor $\mathbf{M} 2$ with $\mathrm{Hg}^{2+}$ was also investigated by ${ }^{1} \mathrm{H}$ NMR titration. As shown in Fig. 7, sensor M2 shows two single peaks at 8.55 and $4.58 \mathrm{ppm}$ in $\mathrm{D}_{2} \mathrm{O}$ solution, which correspond to the protons of the naphthalene rings $\left(\mathrm{H}_{\mathrm{a}}\right)$ and $-\mathrm{CH}_{2}\left(\mathrm{H}_{\mathrm{b}}\right)$, respectively. With the addition of $\mathrm{Hg}^{2+}$, the signal of $-\mathrm{CH}_{2}\left(\mathrm{H}_{\mathrm{b}}\right)$ showed a slight upfield shift, indicating that M2 combined with $\mathrm{Hg}^{2+}$ via the carboxyl group. Moreover, the signal of the naphthalene rings $\left(\mathrm{H}_{\mathrm{a}}\right)$ also showed a slight upfield shift, indicating that the $\pi-\pi$ stacking interactions between the naphthalene rings were involved in the detection process. ${ }^{38}$ Moreover, the XRD patterns (Fig. S6 $\dagger$ ) of the M2- $\mathrm{Hg}^{2+}$ complex showed a peak at $2 \theta=25.67^{\circ}$ corresponding to $d$ spacings of $3.53 \AA$, which also suggested that $\pi-\pi$ stacking existed in the naphthyl groups..$^{39}$ Interestingly, after adding 2.0 equiv. $\mathrm{Hg}^{2+}$, all the ${ }^{1} \mathrm{H}$ NMR signal disappeared. According to these ${ }^{1} \mathrm{H}$ NMR, XRD and IR experiments, we presumed that M2 formed

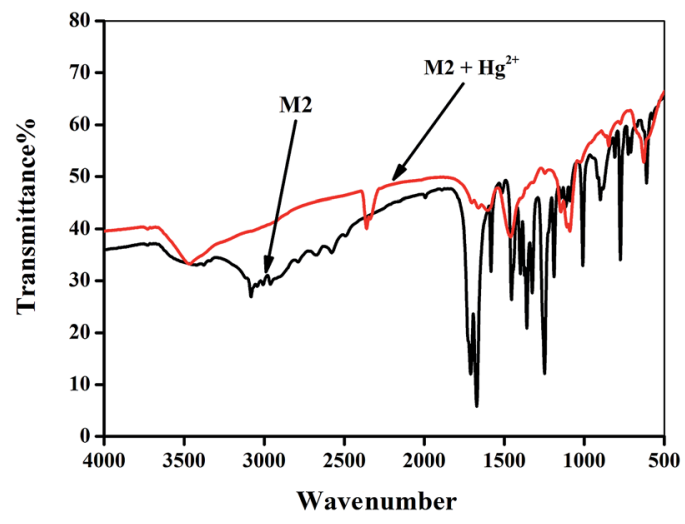

Fig. 6 IR spectra of compound M2 and $\mathrm{M} 2-\mathrm{Hg}^{2+}$ in $\mathrm{KBr}$ disks. 

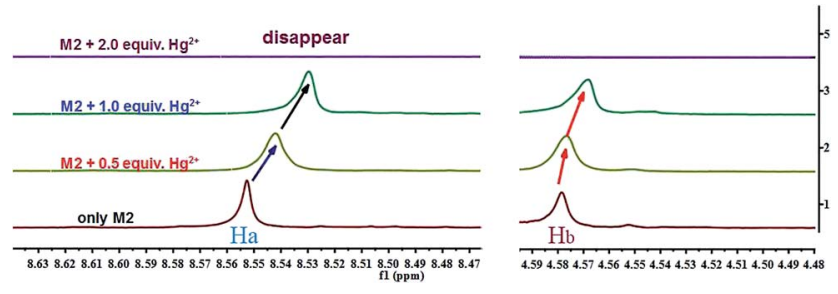

Fig. 7 Partial ${ }^{1} \mathrm{H}$ NMR spectra $\left(600 \mathrm{MHz}, \mathrm{D}-\mathrm{H}_{2} \mathrm{O}\right)$ of free M2 (0.1 M) and in the different concentration of $\mathrm{Hg}^{2+}$ respectively.

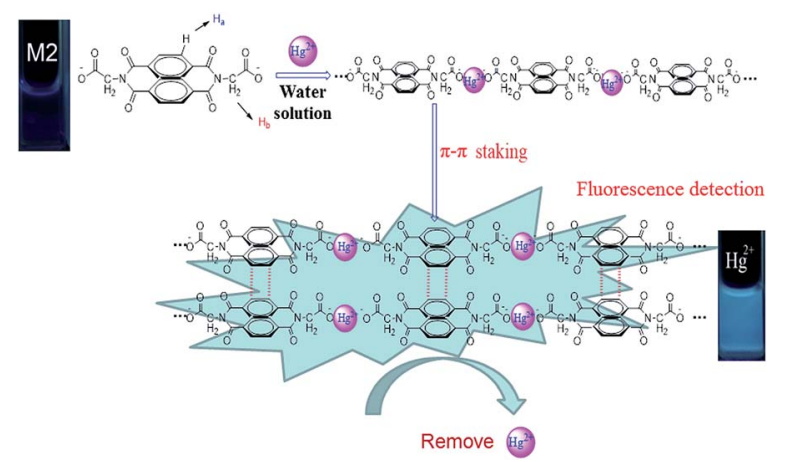

Scheme 2 Possible mechanism for the sensing and removal of $\mathrm{Hg}^{2+}$ by the sensor $\mathrm{M} 2$ in water.

a coordination polymer with $\mathrm{Hg}^{2+}$ and, simultaneously, each coordination polymer chain stacked together through the $\pi-\pi$ interactions (Scheme 2).

Then, we further measured the capacity of the removal of $\mathrm{Hg}^{2+}$ by sensor $\mathbf{M} 2$ via inductively coupled plasma (ICP) analysis in aqueous solution (see ESI $\dagger$ ). The ICP analysis identified an efficient removal of $\mathrm{Hg}^{2+}$. In order to assess the ingestion capacity of the sensor for $\mathrm{Hg}^{2+}$ in water for potential practical applications, $\mathbf{M} 2(0.19 \mathrm{mg})$ was suspended in a dilute aqueous solution of $\mathrm{Hg}\left(\mathrm{ClO}_{4}\right)_{2}(0.20 \mathrm{mg}$ in $5.0 \mathrm{~mL})$, and precipitation was found to occur. We separated the precipitate by centrifugation $(20 \mathrm{~min})$ and gained the supernatant liquor $(5 \mathrm{~mL})$. The ICP analysis verified that the concentration of the residual $\mathrm{Hg}^{2+}$ in water was less than $0.2 \mathrm{ppm}$, indicating that over $98 \%$ of $\mathrm{Hg}^{2+}$ could be effectively removed. This data indicated that $\mathrm{Hg}^{2+}$ could be effectively removed even in extremely dilute solutions.

In summary, a novel water-soluble $\mathrm{Hg}^{2+}$ sensor $\mathbf{M 2}$ was designed and synthesized via an easy to make method. The sensor M2 employs carboxyl groups as hydrophilic groups and $\mathrm{Hg}^{2+}$ binding sites, while NDI moieties act as signal groups and $\pi-\pi$ stacking sites. Interestingly, the sensor M2 could fluorescently "turn-on" when it detected $\mathrm{Hg}^{2+}$ in water with high selectivity and sensitivity. Moreover and more meaningfully, the sensor $\mathbf{M} 2$ can remove $\mathrm{Hg}^{2+}$ from a water solution effectively via the formation of a $\mathbf{M} 2-\mathrm{Hg}^{2+}$ coordination polymer. Therefore, the sensor M2 can be used as an easy to make and efficient sensor for fluorescence detection as well as for the removal of $\mathrm{Hg}^{2+}$ in water.

\section{Acknowledgements}

This study was supported by the National Natural Science Foundation of China (NSFC) (No. 21662031; 21661028; 21574104; 21262032), the Natural Science Foundation of Gansu Province (1506RJZA273) and the Program for Changjiang Scholars and Innovative Research Team in University of Ministry of Education of China (IRT 15R56).

\section{Notes and references}

1 C. Caltagirone and P. A. Gale, Chem. Soc. Rev., 2009, 38, 520.

2 K. P. Carter, A. M. Young and A. E. Palmer, Chem. Rev., 2014, 114, 4564.

3 S. V. Krivovichev, O. Mentré, O. I. Siidra, M. Colmont and S. K. Filatov, Chem. Rev., 2013, 113, 6459.

4 N. Busschaert, C. Caltagirone, W. V. Rossom and P. A. Gale, Chem. Rev., 2015, 115, 8038.

5 C. T. Driscoll, R. P. Mason, H. M. Chan, D. J. Jacob and N. Pirrone, Environ. Sci. Technol., 2013, 47, 4967.

6 R. Zare-Dorabei, R. Rahimi, A. Koohi and S. Zargari, RSC Adv., 2015, 5, 93310.

7 (a) L. Campbell, D. G. Dixon and R. E. Hecky, J. Toxicol. Environ. Health, Part B, 2003, 6, 325; (b) D. G. Streets, M. K. Devane, Z. Lu, T. C. Bond, E. M. Sunderland and D. J. Jacob, Environ. Sci. Technol., 2011, 45, 10485; (c) C. Jiang, Z. Guan, S. Y. Rachel Lim, L. Polavarapu and Q. H. Xu, Nanoscale, 2011, 3, 3316; (d) Y. Chen, L. Wu, Y. Chen, N. Bi, X. Zheng, H. Qi and M. Qin, Microchim. Acta, 2012, 177, 341.

8 (a) W. Ren, C. Zhu and E. Wang, Nanoscale, 2012, 4, 5902; (b) E. O. Ganbold, J. H. Park, K. S. Ock and S. W. Joo, Bull. Korean Chem. Soc., 2011, 32, 519; (c) P. Li, H. Liu, L. Yang and J. Liu, Talanta, 2013, 106, 381.

9 J. Duan, M. Yang, Y. Lai, J. Yuan and J. Zhan, Anal. Chim. Acta, 2012, 723, 88.

10 H. H. Harris, I. J. Pickering and G. N. George, Science, 2003, 301.

11 P. B. Tchounwou, W. K. Ayensu, N. Ninashvili and D. Sutton, Environ. Toxicol., 2003, 18, 149.

12 A. Curley, V. A. Sedlak, E. F. Girling, R. E. Hawk, W. F. Barthel, P. E. Pierce, et al., Science, 1971, 2, 65.

13 I. Onyido, A. R. Norris and E. Buncel, Chem. Rev., 2004, 104, 5911.

14 I. Samb, J. Bell, P. Y. Toullec, V. Michelet and I. Leray, Org. Lett., 2011, 13, 1182.

15 X. Ma, J. Wang, Q. L. Shan, Z. W. Tan, G. H. Wei, D. B. Wei and Y. G. A. Du, Org. Lett., 2012, 14, 820.

16 (a) Z. S. Qian, X. Y. Shan, L. J. Chai, J. J. Ma, J. R. Chen and H. Feng, ACS Appl. Mater. Interfaces, 2014, 6, 6797; (b) P. F. Wei, D. B. Li, B. B. Shi, Q. Wang and F. Huang, Chem. Commun., 2015, 51, 15169; (c) C. H. Yao, Y. H. Cao, Q. Wang, Y. Pan, J. L. Jiang and L. Y. Wang, Chem. Commun., 2016, 52, 8715; (d) C. Jin, M. Zhang, L. Wu, Y. F. Guan, Y. Pan, J. L. Jiang, C. Lin and L. Y. Wang, Chem. Commun., 2013, 49, 2015. 
17 (a) M. Xue, Y. Yang, X. Chi, Z. Zhang and F. Huang, Acc. Chem. Res., 2012, 45, 1294; (b) L. Y. Wang, L. H. Zhu and D. Cao, New J. Chem., 2015, 39, 7211; (c) X. Y. Hu, X. Wu, Q. Duan, T. Xiao, C. Lin and L. Wang, Org. Lett., 2012, 14, 4826; (d) L. Y. Wang, X. G. Chen and D. Cao, RSC Adv., 2016, 6, 96676.

18 (a) W. Ren, Y. Zhang, H. G. Chen, H. Z. F. Gao, N. B. Li and H. Q. Luo, Anal. Chem., 2016, 88, 1385; (b) K. Johari, N. Saman, S. T. Song, S. C. Cheu, H. Kong and H. Mat, Chemosphere, 2016, 156, 56; (c) S. Sun, X. Y. Hu, D. Chen, J. Shi, Y. Dong, C. Lin, Y. Pan and L. Wang, Polym. Chem., 2013, 4, 2224; (d) Y. Chen, M. He, B. Li, L. Wang, H. Meier and D. Cao, RSC Adv., 2013, 3, 21405.

19 E. M. Nolan and S. J. Lippard, Chem. Rev., 2008, 108, 3443. 20 D. T. Quang and J. S. Kim, Chem. Rev., 2010, 110, 6280.

21 C. Zhu, L. Li, F. Fang, J. Chen and Y. Wu, Chem. Lett., 2005, 34, 898.

22 M. A. Nolan and S. P. Kounaves, Anal. Chem., 1999, 71, 3567.

23 L. J. Fan, Y. Zhang and W. E. Jones, Macromolecules, 2005, 38, 2844.

24 P. Chen and C. He, J. Am. Chem. Soc., 2004, 126, 728.

25 A. S. K. Kumar and S. J. Jiang, RSC Adv., 2015, 5, 6294.

26 C. T. Driscoll, R. P. Mason, H. M. Chan, D. J. Jacob and N. Pirrone, Environ. Sci. Technol., 2013, 47, 4967.

27 F. Di Natale, A. Erto, A. Lancia and D. Musmarra, J. Hazard. Mater., 2011, 192, 1842.

28 R. Qu, C. Wang, C. Sun, C. Ji, G. Cheng, X. Wang and G. Xu, Polym. Sci., 2004, 92, 1646.
29 C. Wang, S. Tao, W. Wei, C. Meng, F. Liu and M. Han, J. Mater. Chem., 2010, 20, 4635.

30 A. Chojnacki, K. Chojnacka, J. Hoffmann and H. Gorecki, Miner. Eng., 2004, 17, 933.

31 P. Martellaro, G. Moore, E. Peterson, E. Abbott and A. Gorenbain, Sep. Sci. Technol., 2001, 36, 1183.

32 S. Y. Ding, M. Dong, Y. W. Wang, Y. T. Chen, H. Z. Wang, C. Y. Su and W. Wang, J. Am. Chem. Soc., 2016, 138, 3031.

33 A. Tadjarodi, S. M. Ferdowsi and Z. D. Rouholah, Ultrason. Sonochem., 2016, 33, 118.

34 (a) Q. Lin, F. Zheng, L. Liu, P. P. Mao, Y. M. Zhang, H. Yao and T. B. Wei, RSC Adv., 2016, 6, 111928; (b) Q. Lin, T. T. Lu, X. Zhu, T. B. Wei, H. Li and Y. M. Zhang, Chem. Sci., 2016, 7, 5341; (c) Q. Lin, T. T. Lu, X. Zhu, B. Sun, Q. P. Yang, T. B. Wei and Y. M. Zhang, Chem. Commun., 2015, 51, 1635.

35 (a) T. B. Wei, J. F. Chen, X. B. Cheng, H. Li, B. B. Han, Y. M. Zhang, H. Yao and Q. Lin, Org. Chem. Front., 2017, 4, 210; (b) Q. Lin, B. Sun, Q. P. Yang, Y. P. Fu, X. Zhu, T. B. Wei and Y. M. Zhang, Chem.-Eur. J., 2014, 20, 11457; (c) X. B. Cheng, H. Li, F. Zheng, Q. Lin, H. Yao, Y. M. Zhang and T. B. Wei, RSC Adv., 2016, 6, 20987.

36 Analytical Methods Committee, Analyst, 1987, 112, 199. 37 A. A. Markeb and N. A. El-Maali, Talanta, 2014, 119, 417.

38 L. Y. Wang, L. H. Zhu and D. R. Cao, New J. Chem., 2015, 39, 7211.

39 C. Po, Z. Ke, A. Y. Y. Tam, H. F. Chow and V. W. W. Yam, Chem.-Eur. J., 2013, 19, 15735. 